\title{
Analisis Keragaman Genetik Isolat Bakteri Xanthomonas oryzae pv. oryzae dari Jawa Barat dan Jawa Tengah Berdasarkan Analisis ARDRA Gen 16SrRNA
}

\author{
Genetic Diversity Analysis of Bacterial Isolates \\ Xanthomonas oryzae pv. oryzae from West Java and Central Java \\ Using ARDRA 16SrRNA Gene Analysis
}

\author{
Yadi Suryadi $^{1{ }^{*}}$, Dwi N. Susilowati ${ }^{1}$, Puji Lestari ${ }^{1}$, Sutoro ${ }^{1}$, Manzila Ifa ${ }^{1}$, Trini Suryani Kadir ${ }^{2}$ \\ Sheryn Sunni Albani ${ }^{3}$, I Made Artika ${ }^{3}$ \\ ${ }^{1}$ Balai Besar Penelitian Bioteknologi dan Sumberdaya Genetik Pertanian, Bogor 16111 \\ ${ }^{2}$ Balai Besar Penelitian Tanaman Padi, Subang 41256 \\ ${ }^{3}$ Institut Pertanian Bogor, Bogor 16680
}

\begin{abstract}
ABSTRAK
Keragaman genetik lima belas isolat Xanthomonas oryzae pv. oryzae yang berasal dari beberapa daerah di Jawa Barat dan Jawa Tengah telah dianalisis menggunakan amplified ribosomal DNA restriction analysis (ARDRA) gen 16SrRNA. Pola ARDRA yang terbentuk dari hasil pemotongan dengan enzim restriksi $R s a$ I menghasilkan sebanyak 13 pola yang menunjukkan keragaman genetika isolat $X$. oryzae pv. oryzae yang diuji cukup tinggi. Berdasarkan pohon filogenetika yang terbentuk, beberapa isolat memiliki kekerabatan yang cukup dekat. Isolat $X$. oryzae pv. oryzae $1 / 96 \mathrm{pml}$ dan $61 \mathrm{pml}$ secara genetik cukup dekat dengan isolat $29 \mathrm{~d}, 59 \mathrm{pml}$, dan $60 \mathrm{pml}$ meskipun berasal dari daerah yang berbeda-beda. Isolat lain yang memiliki hubungan kekerabatan cukup dekat ialah isolat $X$. oryzae pv. oryzae $5 \mathrm{mgl}$ dengan isolat $23 \mathrm{~d}, 28 \mathrm{~d}$, dan dan $10 \mathrm{sbg}, 8 \mathrm{myd}$, serta isolat $6 \mathrm{klt}$ dengan isolat 3 ind dan $2 \mathrm{kr}$. Hasil keragaman genetika ini dapat dijadikan acuan dalam seleksi galur/isolat $X$. oryzae pv. oryzae untuk pengembangan tanaman padi tahan hawar daun bakteri di Indonesia
\end{abstract}

Kata kunci: filogenetika, hawar daun bakteri, keragaman genetika, padi

\begin{abstract}
Fifteen Xanthomonas oryzae pv. oryzae isolates from several regions in West Java and Central Java have been studied for their genetic diversity using amplified ribosomal DNA restriction analysis (ARDRA) 16SrRNA gene.Total of 13 ARDRA patterns from digestion of DNA with RsaI restriction enzyme was obtained, indicated higher genetic diversity of $X$. oryzae pv. oryzae. Phylogenetic analysis revealed a close genetic relationships among isolates. Isolates $X$. oryzae pv. oryzae $1 / 96 \mathrm{pml}$ and $61 \mathrm{pml}$ are closely related with isolates $29 \mathrm{~d}, 59 \mathrm{pml}$, and $60 \mathrm{pml}$ although they are isolated from different locations. The other closely related isolates were between $X$. oryzae pv. oryzae $5 \mathrm{mgl}$ with $23 \mathrm{~d}, 38 \mathrm{~d}, 10 \mathrm{sbg}$, 8myd; while $6 \mathrm{klt}$ was close to 3 ind and $2 \mathrm{kr}$. The result of $X$. oryzae pv. oryzae genetic diversity can be used as a reference for strain or/isolates selection for development ofbacterial leaf blight resistance in Indonesia
\end{abstract}

Key words: bacterial leaf blight, phylogenetic, restriction enzyme, rice

*Alamat penulis korespondensi: Jurusan Hama dan Penyakit Tumbuhan, Fakultas Pertanian, Universitas Sriwijaya Jalan Raya Palembang-Prabumulih Km 32, Indralaya, Ogan Ilir 30662

Tel: 0711-580663, Faks: 0711-580059, Surel: Limpal2003@yahoo.com 


\section{PENDAHULUAN}

Bakteri Xanthomonas oryzae pv. oryzae merupakan patogen penyebab penyakit hawar daun bakteri (HDB) pada padi. Serangan penyakit HDB menyebabkan turunnya produksi padi dan dapat menyebabkan kehilangan hasil panen. Tahun 2010 luas lahan yang terserang penyakit HDB sebesar 54796 ha dan serangan ini meningkat pada masa tanam 2010-2011 menjadi sebesar 64123 ha (Direktorat Perlindungan Tanaman Pangan 2011). Pengendalian penyakit HDB melalui pengembangan varietas tahan HDB merupakan salah satu cara yang efektif, murah, dan mudah diterapkan pada petani. Keragaman genetika yang luas pada bakteri $X$. oryzae pv. oryzae di berbagai daerah di Indonesia memerlukan pengembangan varietas padi yang tahan dan harus disesuaikan dengan penyebaran galur atau patotipenya.

Sampai saat ini paling tidak telah dilaporkan adanya 12 patotipe $X$. oryzae pv. oryzae di Indonesia yang berbeda variabilitas patogenisitasnya antar lokasi maupun musim sehingga menyulitkan upaya pengendalian $X$. oryzae pv. oryzae secara efektif. Dominasi populasi patotipe erat kaitannya dengan musim dan jenis varietas yang ditanam di lapangan (Sudir et al. 2009). Upaya pergiliran gen ketahanan (gene deployment) sangat bermanfaat untuk mengendalikan patogen $X$. oryzae pv. oryzae secara spesifik lokasi. Pengetahuan tentang penyebaran patotipe beserta variabilitasnya sangat penting dikaji untuk dijadikan pijakan perlunya dilakukan analisis keragaman genetik pada daerah yang diteliti.

Analisis keragaman genetik untuk karakterisasi patogen $X$. oryzae pv. oryzae dapat dilakukan menggunakan teknik molekuler karena cepat dan sensitif. Gen 16SrRNA dapat dilakukan dengan metode restriction fragment length polymorphism (RFLP) berdasarkan analisis pengukuran perbedaan panjang fragmen DNA yang dihasilkan oleh pemotongan enzim restriksi yang disebut amplified rDNA restriction analysis (ARDRA) (Schlegel et al. 2003).
Berdasarkan pola pita yang dihasilkan dari pemotongan enzim restriksi, pohon filogenetika dapat direkonstruksi dan dapat mengelompokkan bakteri berdasarkan jarak genetikanya.

Identifikasi keragaman genetika isolat bakteri X. oryzae pv. oryzae dari berbagai daerah di Indonesia, diharapkan dapat membantu pengembangan varietas padi tahan penyakit HDB. Tujuan penelitian ialah mengarakterisasi keragaman genetik 15 isolat $X$. oryzae pv. oryzae yang diperoleh dari beberapa daerah di Jawa Barat dan Jawa Tengah menggunakan analisis ARDRA.

\section{BAHAN DAN METODE}

\section{Isolat Xanthomonas oryzae pv. oryzae dan Isolasi DNA}

Sebanyak 15 isolat bakteri $X$. oryzae pv. oryzae yang berasal dari beberapa daerah di Jawa Barat dan Jawa Tengah (Tabel 1) diisolasi pada medium agar-agar Wakimoto (AW) (larutan sari kentang, $0.125 \mathrm{~g} \mathrm{Ca}\left(\mathrm{NO}_{3}\right)_{2}$. $4 \mathrm{H}_{2} \mathrm{O}, 0.5 \mathrm{~g} \mathrm{Na}_{2} \mathrm{HPO}_{4}$. $12 \mathrm{H}_{2} \mathrm{O}, 3.75 \mathrm{~g}$ sukrosa, dan $1.25 \mathrm{~g}$ pepton dengan $\mathrm{pH}$ 7-8). Isolat murni bakteri diremajakan pada agar-agar miring medium AW dan diinkubasi selama kurang 3-5 hari sampai muncul koloni berwarna kuning dan berlendir.

Isolasi DNA genom bakteri dilakukan menggunakan metode Lazo et al. (1987) yang dimodifikasi. Sebanyak $5 \mathrm{~mL}$ biakan sel bakteri dalam nutrient broth (NB) disentrifugasi pada kecepatan 8000 x g selama 10 menit pada suhu $4{ }^{\circ} \mathrm{C}$. Pelet dicuci dan disuspensi kembali dengan $1 \mathrm{~mL}$ bufer STE, kemudian disentrifugasi kembali pada kecepatan 8000 x g selama 10 menit pada suhu $4{ }^{\circ} \mathrm{C}$. Pelet disuspensi kembali dalam $200 \mu \mathrm{L}$ bufer STE dan ditambahkan $40 \mu \mathrm{L}$ larutan sodium dodecyl sulphate (SDS) 10\%. Suspensi diinkubasi dalam oven pada suhu $65{ }^{\circ} \mathrm{C}$ selama 1.5 jam lalu didinginkan pada suhu ruang. Suspensi ditambah $4 \mu \mathrm{L}$ Proteinase-K $10 \mathrm{mg} \mathrm{mL}^{-1}$, lalu diinkubasi dalam oven pada suhu $37{ }^{\circ} \mathrm{C}$ selama 4 jam. Suspensi ditambahi 200-400 $\mu \mathrm{L}$ bufer STE, selanjutnya ditambah larutan fenol dan 
kloroform, masing-masing sebanyak $120 \mu \mathrm{L}$. Tahap ini dilakukan secara perlahan sampai terbentuk emulsi. Suspensi yang telah teremulsi lalu disentrifugasi pada kecepatan $10000 \mathrm{x} \mathrm{g}$ selama 15 menit. Supernatan dipindahkan ke tabung mikro steril dan dipresipitasi dengan menambahkan EtOH 95\% dingin sebanyak $2 \mathrm{x}$ volume supernatan. Suspensi selanjutnya diinkubasi pada suhu $-20^{\circ} \mathrm{C}$ selama 30 menit. Suspensi disentrifugasi pada kecepatan $8000 \mathrm{x}$ g selama 2 menit lalu supernatannya dibuang. Pelet dikeringudarakan selama kurang lebih 2 jam dan disuspensikan kembali dalam 20 $\mu \mathrm{L}$ bufer TE yang mengandung $10 \mu \mathrm{g} \mathrm{mL}^{-1}$ RNase. Suspensi yang mengandung DNA ini disimpan pada suhu $-20{ }^{\circ} \mathrm{C}$ untuk digunakan pada tahap selanjutnya.

\section{Amplifikasi Gen 16S-rRNA dan Pemotongan dengan Enzim Restriksi RsaI}

Sebanyak $2 \mu \mathrm{L}$ DNA (20 ng/ $\mu \mathrm{L})$ ditambah dengan $10 \mu \mathrm{L}$ nuclease free water. Volume total reaksi PCR sebanyak $20 \mu \mathrm{L}$. Campuran bahan untuk PCR terdiri atas $2 \mu \mathrm{L}$ DNA, 12.5 $\mu \mathrm{L}$ GoTaq master mix, masing-masing $1 \mu \mathrm{L}$ primer 63F (5'-CAG GCC TAA CAC ATG CAA GTC-3') dan 1387R(5'-GGG CGG WGT GTA CAA GGC-3') (Marchessi et al.1998) dan $8.5 \mu \mathrm{L} \mathrm{ddH}_{2} \mathrm{O}$. Amplifikasi dilakukan pada kondisi suhu denaturasi awal $94{ }^{\circ} \mathrm{C}$ selama 5 menit dengan 1 siklus, denaturasi $94{ }^{\circ} \mathrm{C}$ selama 1 menit 30 detik, penempelan $55^{\circ} \mathrm{C}$ selama 45 detik, dan pemanjangan $72{ }^{\circ} \mathrm{C}$ selama 1 menit dengan total 30 siklus, pemanjangan akhir $72{ }^{\circ} \mathrm{C}$ selama 1 menit dengan 1 siklus. Amplikon dielektroferesis pada gel agarosa $1.8 \%$ dalam bufer TAE $0.5 x$ untuk memastikan adanya amplifikasi sebelum dilakukan pemotongan dengan enzim restriksi. Hasil elektroforesis direndam dengan etidium bromida dan divisualisasi menggunakan UV transiluminator.

Hasil amplifikasi gen 16SrRNA dari masing-masing sampel dipotong dengan enzim restriksi $R s a$ I yang mempunyai situs pemotongan (5'-GTAC). Reaksi pemotongan terdiri atas $10 \mu \mathrm{L}$ produk PCR, $18 \mu \mathrm{LddH}_{2} \mathrm{O}, 2$ $\mu \mathrm{L}$ 10x bufer Tango, dan $1 \mu \mathrm{L}$ enzim restriksi. Campuran tersebut diinkubasi pada suhu $37^{\circ} \mathrm{C}$ selama \pm 20 jam. Hasil pemotongan dielektroforesis pada gel agarosa dengan metode yang sama untuk visualisasi amplikon PCR. Hasil visualisasi dijadikan data biner terhadap pola pita yang terbentuk dan dibuat pohon filogenetikanya menginkuti program MVSP 3.2 dengan metode unweighted pair group method arithmetic mean (UPGMA).

\section{HASIL}

\section{Amplikon Gen 16SrRNA}

Sebanyak 15 isolat $X$. oryzae pv. oryzae, menghasilkan pita-pita DNA total yang dapat digunakan untuk amplifikasi PCR.

Tabel 1 Isolat Xanthomonas oryzae pv. oryzae asal tanaman padi dari beberapa wilayah di Jawa Barat dan Jawa Tengah

\begin{tabular}{lll}
\hline Isolat & Asal varietas padi & \multicolumn{1}{c}{ Asal lokasi } \\
\hline $1 \mathrm{kr}$ & Inpari 18 & Jatisari, Karawang \\
$2 \mathrm{kr}$ & Inpari 18 & Cikalong wetan, Karawang \\
$3 \mathrm{ind}$ & C4 & Gantar, Indramayu \\
$4 \mathrm{mgl}$ & Mentikwangi & Pabelan, Magelang \\
$5 \mathrm{mgl}$ & Lokal & Kaliduren, Doroyudan \\
$6 \mathrm{klt}$ & Ciherang & Kepanjen, Klaten \\
$8 \mathrm{myd}$ & Ciherang & Mayudan, Klaten \\
$10 \mathrm{sbg}$ & Ciherang & Sukamandi Jaya, Subang \\
$23 \mathrm{~d}$ & Inpari10 & Pusakaratu, Subang \\
$28 \mathrm{~d}$ & Hipa6 & Sukamandi,Subang \\
$29 \mathrm{~d}$ & Ciherang & Ciasem, Subang \\
$59 \mathrm{pml}$ & Si denok & Comal, Pemalang \\
$60 \mathrm{pml}$ & Ciherang & Comal, Pemalang \\
$61 \mathrm{pml}$ & Ciherang & Pekuden, Pemalang \\
$1 / 96 \mathrm{pml}$ & Ciherang & Pemalang \\
\hline
\end{tabular}




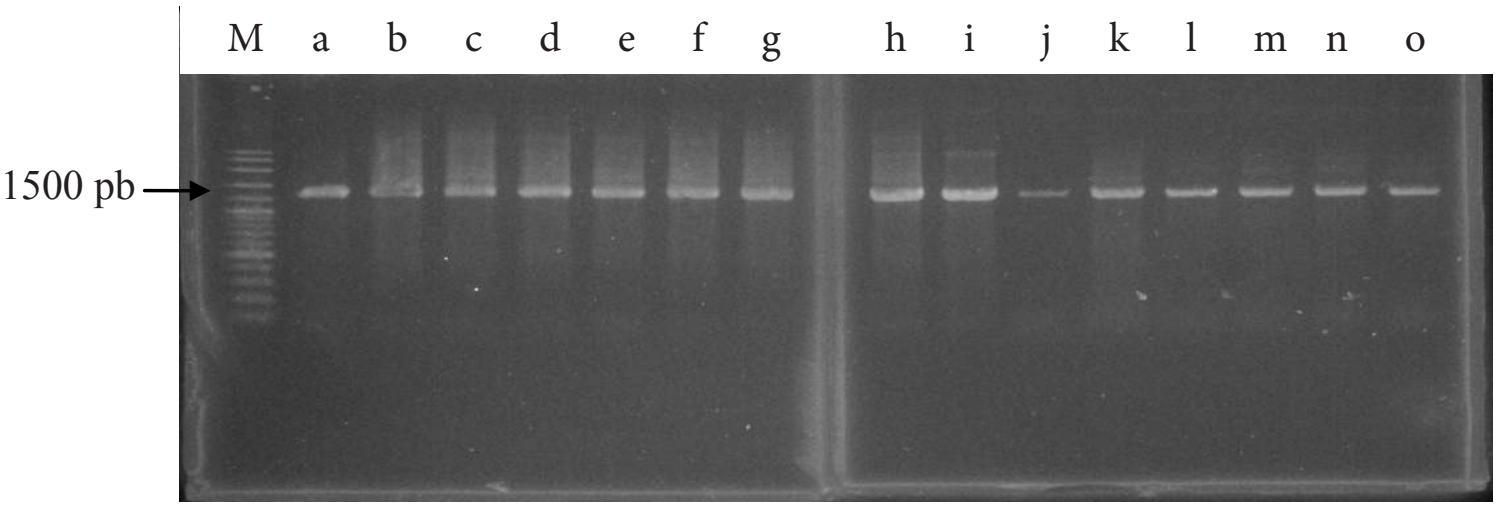

Gambar 1 Amplikon gen 16S-rRNA 15 isolat Xanthomonas orizae pv. oryzae. M, MW (100 bp); a, 1kr; b, 2kr; c, 3ind; d, 4mgl; e, 5mgl; f, 6klt; g, 8myd; h, 10sbg; i, 23d; j, 28d; k, 29d; 1, 59pml; m, 60pml; n, 61 pml; o, 1/96pml.
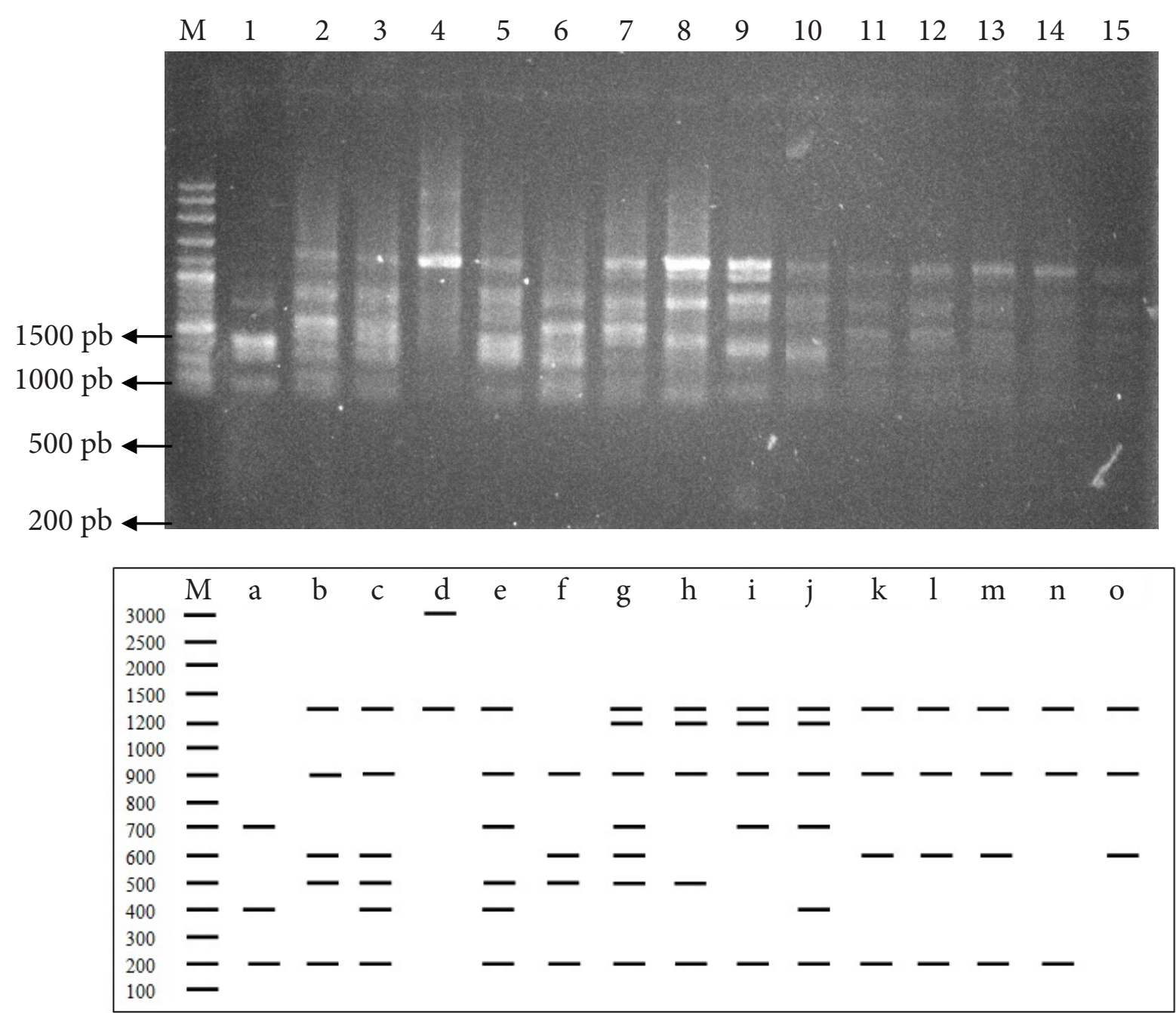

Gambar 2 Hasil pemotongan gen 16S-rRNA Xanthomonas orizae pv. oryzae. dengan enzim restriksi RsaI. M, MW (100 pb) dan interpretasi elektroforegram hasil pemotongan gen 16SrRNA dengan enzim restriksi RsaI dan pola ARDRA yang terbentuk. M, MW (100 pb); a, 1kr; b, 2kr; c, 3ind; d, 4mgl; e, 5mgl; f, 6klt; g, 8myd; h, 10sbg; i, 23d; j, 28d; k, 29d; 1, 59pml; m, 60pml; n, 61pml; o, 1/96pml. 
DNA genomik yang dihasilkan mempunyai nilai nisbah kisaran kemurnian DNA 1.82 pada panjang gelombang 260/280 yang menunjukkan kualitasnya cukup baik untuk digunakan pada proses PCR. Visualisasi pita DNA menunjukkan kemurnian DNA hasil isolasi yang diperoleh konsentrasinya cukup apabila diamplifikasi.

Gen 16SrRNA pada 15 isolat $X$. oryzae pv. oryzae berhasil diamplifikasi dengan PCR

Tabel 2 Pengelompokan ukuran pola pita hasil pemotongan dengan enzim restriksi $R s a \mathrm{I}$

\begin{tabular}{ll}
\hline $\begin{array}{l}\text { Pola } \\
\text { pita }\end{array}$ & \multicolumn{1}{c}{\begin{tabular}{c}
\multicolumn{1}{c}{$\begin{array}{c}\text { Ukuran basa } \\
(\mathrm{pb})\end{array}$} \\
$\mathrm{a}$
\end{tabular}} \\
$\mathrm{b}$ & $200,700,400$ \\
$\mathrm{c}$ & $200,500,600,900,1300-1400$ \\
$\mathrm{~d}$ & $1300-1400,500,600,900,1300-1400$ \\
$\mathrm{e}$ & $200,400,500,700,900,1300-1400$ \\
$\mathrm{f}$ & $200,500,600,900$ \\
$\mathrm{~g}$ & $200,500,600,700,900,1200,1300-1400$ \\
$\mathrm{~h}$ & $200,500,900,1200,1300-1400$ \\
$\mathrm{i}$ & $200,700,900,1200,1300-1400$ \\
$\mathrm{j}$ & $200,400,700,900,1200,1300-1400$ \\
$\mathrm{k}$ & $200,600,900,1300-1400$ \\
$\mathrm{l}$ & $200,900,1300-1400$ \\
$\mathrm{~m}$ & $600,900,1300-1400$ \\
\hline
\end{tabular}

sehingga menghasilkan produk PCR berupa pita tunggal yang berada pada kisaran 1400 $1500 \mathrm{pb}$ (Gambar 1).

\section{Amplified rDNA Restriction Analysis (ARDRA)}

Fragmen DNA hasil amplifikasi $X$. oryzae pv. oryzae yang dipotong dengan enzim restriksi $R s a$ I menghasilkan 13 pola pita ARDRA yang ditandai dengan huruf a sampai $\mathrm{m}$ dan interpretasi elektroforegram hasil pemotongan dengan enzim restriksi $R s a \mathrm{I}$ (Gambar 2). Penghitungan ukuran pita hasil pemotongan dengan enzim restriksi dilihat berdasarkan marka yang digunakan. Ukuran pita terbesar $3000 \mathrm{pb}$ terdapat pada kode isolat Xoo 4mgl, sedangkan pita terkecil 200 pb terdapat pada hampir setiap kode isolat (Tabel 2). Sebanyak 13 pola ARDRA yang terbentuk dari hasil pemotongan dengan enzim restriksi dijadikan data biner sebagai input data untuk pembentukan pohon filogenetika. Pohon filogenetika berdasarkan pola pita ARDRA yang terbentuk pada cut off $0.3 \mathrm{~kb}$ menunjukkan dua klaster utama dari 15 isolat $X$. oryzae pv. oryzae yang diuji. Ada 6 isolat $X$. oryzae pv. oryzae yang lebih dekat secara genetika dalam klaster pertama (I), yaitu 61pml, $4 \mathrm{mgl}$, 59pml, 1/96pml, 60pml, dan 29d. Sebagian besar isolat teridentifikasi dalam klaster II,

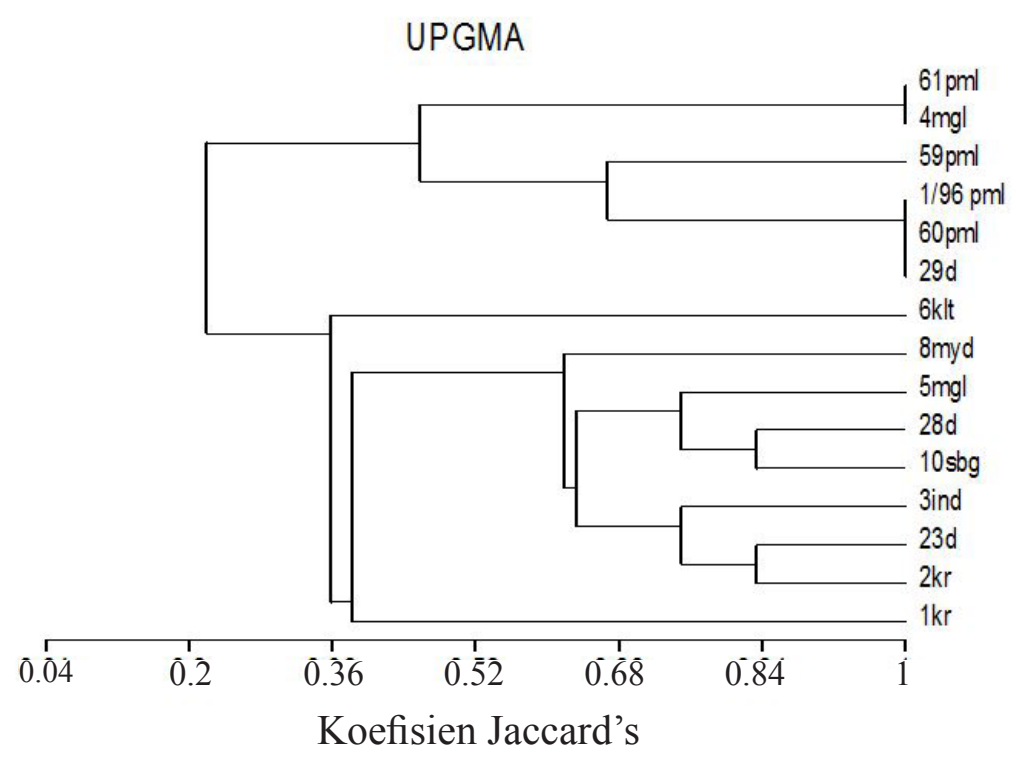

Gambar 3 Pohon filogenetika Xanthomonas orizae pv. oryzae berdasarkan pola pita DNA hasil pemotongan dengan enzim restriksi RsaI. 
yaitu sebanyak 9 isolat meliputi $1 \mathrm{kr}, 2 \mathrm{kr}, 23 \mathrm{~d}$, 3ind, 10sbg, 28d, 5mgl, 8myd, 6klt. Ada 3 isolat $X$. oryzae pv. oryzae, yaitu $29 \mathrm{~d}, 60 \mathrm{pml}$ dan 1/96pml, memiliki kesamaan pola pita ARDRA (Gambar 3) seperti ditunjukkan oleh kedekatan genetika dalam satu klaster.

\section{PEMBAHASAN}

Salah satu teknik yang akurat untuk identifikasi molekuler pada mikroorganisme prokariot khususnya bakteri ialah identifikasi terhadap gen penyandi 16SrRNA yang dikenal juga dengan sebutan ribotyping. Identifikasi tersebut didasarkan pada tingkat kesamaan dalam urutan gen 16SrRNA sebagai sidik jari genetik bakteri atau disebut urutan sidik jari. Beberapa keuntungan dalam analisis terhadap gen penyandi 16SrRNA ini ialah RNA secara umum dimiliki semua bakteri dan merupakan unit yang konstan (Woese et al. 1983). Jika terdapat kemiripan atau sedikit perbedaan basa pada urutan nukleotida gen 16SrRNA dari dua jenis organisme maka kedua organisme tersebut memiliki hubungan kekerabatan yang dekat ditinjau dari kedekatan secara evolusinya (Pangastuti 2006).

Sampai saatinianalisiskeragaman X.oryzae pv. oryzae asal Indonesia telah diobservasi menggunakan beberapa pendekatan molekuler (Tasliah et al. 2013). Mengingat kelebihan teknik ARDRA untuk karakterisasi molekuler berbagai bakteri (Susilowati et al. 2010) maka identifikasi molekuler dalam menganalisis keragaman genetik $X$. oryzae pv. oryzae pada studi ini menggunakan identifikasi terhadap gen penyandi 16SrRNA yang dilanjutkan dengan pemotongan enzim restriksi. Sebanyak 15 isolat $X$. oryzae pv. oryzae dari beberapa sentra daerah padi di Jawa Barat dan Jawa Tengah, berhasil diamplifikasi gen penyandi 16SrRNAnya menggunakan primer $63 \mathrm{~F}$ dan 1387R. Proses amplifikasi ini menghasilkan produk pada kisaran ukuran 1400-1500 pb (Gambar 1). Hampir setiap isolat menghasilkan pita tunggal yang cukup tebal, kecuali isolat $X$. oryzae pv. oryzae $1 / 96 \mathrm{pml}$. Pita yang tebal tersebut menunjukkan bahwa gen 16SrRNA isolat teramplifikasi dengan baik. Hal ini dapat disebabkan oleh beberapa faktor yang mempengaruhi PCR, optimasi amplifikasi PCR dari DNA tiap isolat dan kesesuaian primer yang digunakan. Primer yang digunakan adalah primer spesifik $63 \mathrm{~F}$ dan 1387R. Primer 63F memiliki panjang urutan basa 21 nukleotida dan 1387R sebanyak 18 nukleotida. Primer ini tidak membentuk struktur dupleks dengan ujung 5' yang dapat dikenali enzim eksonuklease dan tidak terdapat nukleotida yang terpotong pada ujung 5'. Hal ini dapat mempengaruhi suhu penempelan primer (Marchessi et al. 1998) sehingga dapat membantu proses amplifikasi DNA.

ARDRA merupakan teknik RFLP yang digunakan untuk mengetahui perbedaan jenis bakteri, misalnya berdasarkan gen ribosomal DNA seperti 16SrRNA. Teknik ini menggunakan enzim restriksi untuk melihat polimorfisme dalam genom organisme. Situs enzim restriksi dari genom suatu kelompok organisme yang kemudian berubah karena mutasi atau berpindah karena genetic rearrangement dapat menyebabkan situs tersebut tidak lagi dikenali oleh enzim atau enzim restriksi akan memotong daerah lain yang berbeda. Proses ini menyebabkan terbentuknya fragmen-fragmen DNA yang berbeda ukurannya antara satu organisme dengan organisme lainnya. Polimorfisme ini selanjutnya digunakan sebagai dasar untuk membuat pohon filogenetika atau dendogram kekerabatan kelompok (Sasaki et al. 2004).

Enzim restriksi yang digunakan untuk memotong produk PCR 16SrRNA dari 15 isolat $X$. oryzae pv. oryzae, yaitu $R s a \mathrm{I}$. Enzim $R s a$ I merupakan enzim endonuklease restriksi tetramerik atau memiliki sisi pengenalan empat basa sehingga bila penyebaran nukleotida terjadi secara acak pada organisme dengan $\mathrm{G}+\mathrm{C}$ sekitar 50\% maka sekitar 256 pb dapat diharapkan memiliki satu sisi pengenalan. Enzim restriksi tersebut menghasilkan sejumlah besar fragmen yang bervariasi ukurannya (Susilowati et al. 2010).

Enzim restriksi RsaI memotong dengan sifat blunt end pada situs 5'...GT $\downarrow$ AC...3' dan 3'...CA $\uparrow$ TG...5'. Pemotongan dengan RsaI pada isolat $X$. oryzae pv. oryzae yang 
diuji menghasilkan 13 pola pita ARDRA yang berbeda. Pengelompokan tersebut berdasarkan kesamaan di situs pemotongan enzim restriksi $R s a \mathrm{I}$ pada setiap spesies. Isolat X. oryzae pv. oryzae dengan kode 29d, 59pml, dan $60 \mathrm{pml}$ memiliki hasil pola pita yang sama sehingga dikelompokkan dalam satu pola pita. Kesamaan pola yang dihasilkan isolat $X$. oryzae pv. oryzae $59 \mathrm{pml}$ dan $60 \mathrm{pml}$ tersebut dapat disebabkan oleh kesamaan daerah asal kedua isolat tersebut, yaitu Pemalang. Isolat Xoo29d berasal dari Subang, namun memiliki pola pita yang sama dengan isolat 59pml dan $60 \mathrm{pml}$. Hal ini dapat diartikan bahwa ketiga isolat tersebut memiliki kekerabatan yang sangat dekat meskipun berasal dari daerah yang berbeda.

Hasil penelitian menunjukkan adanya keragaman genetika antar isolat yang diuji meskipun isolat diperoleh dari daerah yang sama atau berbeda lokasi khususnya di Jawa Barat dan Jawa Tengah. Dengan demikian, pergiliran tanaman akan semakin kompleks mengingat dominansi patotipe $X$. oryzae pv. oryzae akan berbeda antar lokasi di Indonesia. Keragaman genetik ini dilaporkan juga terjadi di Filipina oleh Ardales et al. (1996) yang melaporkan adanya perbedaan genetika yang cukup besar antar struktur populasi $X$. oryzae pv. oryzae yang diperoleh pada tingkat agroekosistem, area pengambilan contoh antar lapangan dan jenis kultivar.

Berdasarkan pohon filogenetika yang terbentuk, $X$. oryzae pv. oryzae isolat $1 / 96 \mathrm{pml}$ dan $61 \mathrm{pml}$ terdapat dalam satu percabangan dengan isolat $29 \mathrm{~d}, 59 \mathrm{pml}$, dan $60 \mathrm{pml}$. Isolat $1 / 96 \mathrm{pml}$ dan $61 \mathrm{pml}$ berasal dari daerah yang sama dengan isolat 59pml dan 60pml, yaitu Pemalang. Meskipun memiliki pola pita yang berbeda, namun dapat diartikan bahwa isolat 1/96pml dan 61pml memiliki kekerabatan yang cukup dekat dengan isolat 29d, 59pml, dan 60pml. Selanjutnya, isolat $X$. oryzae pv. oryzae 5mgl (Doroyudan) memiliki satu percabangan dengan isolat $23 \mathrm{~d}, 28 \mathrm{~d}, 10 \mathrm{sbg}$, dan 8 myd. X. oryzae pv. oryzae $23 \mathrm{~d}$ dan $28 \mathrm{~d}$ berada dalam satu percabangan kecil. Kedua isolat tersebut berada dalam daerah yang berbeda, namun memiliki kekerabatan yang cukup dekat. $X$. oryzae pv. oryzae $10 \mathrm{sbg}$ dan 8 myd juga berada dalam satu percabangan kecil yang lain. Kedua isolat $X$. oryzae pv. oryzae ini juga berasal dari daerah yang berbeda, namun memiliki kekerabatan yang cukup dekat. Percabangan lain yang terbentuk, yaitu isolat $X$. oryzae pv. oryzae 6klt, 3ind, dan $2 \mathrm{kr}$. Isolat 6klt berasal dari Klaten, 3ind dari Indramayu, dan $2 \mathrm{kr}$ dari Karawang. Ketiga isolat ini memiliki kekerabatan yang juga cukup dekat meskipun berasal dari daerah yang berbeda. Isolat Xoo $1 \mathrm{kr}$ yang berasal dari daerah yang sama dengan isolat $2 \mathrm{kr}$ (Karawang) terdapat dalam percabangan yang berbeda, namun masih dalam satu klaster besar yang sama. Isolat $X$. oryzae pv. oryzae 4mgl (Pabelan, Magelang) berada dalam klaster yang berbeda dengan isolat lain yang diuji. Hal ini menunjukkan kekerabatan isolat 4mgl dengan yang lainnya cukup jauh. Hasil ini dapat memudahkan dalam deteksi $X$. oryzae pv. oryzae di lapangan dan sekaligus untuk pengendalian penyakit (Onasanya et al. 2010).

Menurut Schlegel et al. (2003) tidak terdapat keragaman pada intraspesies dan situs pemotongan yang terkonservasi pada spesies yang berdekatan menunjukkan keragaman yang rendah. Hal ini berbanding terbalik dengan hasil keragaman yang terbentuk dari $X$. oryzae pv. oryzae yang diuji. Hasil pohon filogenetika yang terbentuk menunjukkan keragaman yang cukup tinggi pada isolat $X$. oryzae pv. oryzae yang diuji meskipun berada dalam spesies yang sama. Keragaman genetik yang cukup tinggi dari $X$. oryzae pv. oryzae yang diuji dalam studi ini mungkin disebabkan perbedaan daerah asal setiap isolat atau telah terjadi mutasi dalam sel inang yang berbeda (Mongkolsuk et al. 2000). Berdasarkan penelitian ini terlihat pula adanya campuran patotipe yang diperoleh dari daerah yang sama yang mengimplikasikan perlunya upaya pergiliran menggunakan varietas tahan berlatar belakang gen tahan kombinasi (piramiding gen). Dalam rangka pengendalian HDB, hasil analisis keragaman genetik $X$. oryzae pv. oryzae ini penting artinya dan diperlukan untuk membantu mengembangkan 
varietas padi tahan HDB secara spesifik lokasi di Indonesia.

Sebanyak 15 isolat $X$. oryzae pv. oryzae yang diuji yang berasal dari beberapa daerah di Jawa Barat dan Jawa Tengah, secara genetika menunjukkan keragaman yang cukup tinggi. Berdasarkan analisis gen 16SrRNA, diperoleh sebanyak 13 pola pita ARDRA yang berbeda. Analisis pohon filogenetika menunjukkan bahwa antara isolat $X$. oryzae pv. oryzae yang berasal dari daerah yang berbeda dapat memiliki kekerabatan yang cukup dekat secara genetik.

\section{UCAPAN TERIMA KASIH}

Penulis menyampaikan ucapan terima kasih kepada APBN DIPA RPTP Dr Sutoro No Proyek.1798.009.011 yang telah membiayai penelitian ini.

\section{DAFTAR PUSTAKA}

Ardales EY, Leung H, Cruz CMV, Mew TW, Leach JE. 1996. Hierarchical analysis of spatial variation of the rice bacterial blight pathogen across agroecosystems in the Philippines. Phytopathology. 86:241-252. DOI: http://dx.doi.org/10.1094/ Phyto-86-241.

[DPTP]. Direktorat Perlindungan Tanaman Pangan. 2011. Prakiraan serangan BLB pada padi di Indonesia masa tanam Tahun 2011. Jakarta (ID): Ditjen TP.

Lazo GR, Roffey R, Gabriel DW. 1987. Pathovars of Xanthomonas campestris are distinguishable by restriction fragmentlength polymorphism. IJSEM. 37(3):214221.

Marchessi JR, Sato T, Weightman AJ, Martin TA, Fry JC, Hiom SJ, Wade WG. 1998. Design and evaluation of useful bacteriumspecific PCR primers that amplify genes coding for bacterial 16S rRNA. Appl Environ Microbiol. 64:795-799.

Mongkolsuk S, Wangshuk W, Tuangthong M, Loprasert S. 2000. Mutation in oxyr resulting in peroxide resistance in Xanthomonas campestris. J Bacteriol.
182:3846-3849. DOI: http://dx.doi.org/10. 1128/JB.182.13.3846-3849.2000.

Onasanya A, Basso A, Somado E, Gasore ER, Nwilene FE, Ingelbrecht I, Lamo J, Wydra K. 2010. Development of combined molecular diagnostic and DNA fingerprinting technique for rice bacteria pathogens in Africa. Biotechnol. 9:89-105. DOI: http://dx.doi.org/10.3923/biotech. 2010.89.105.

Pangastuti A. 2006. Definisi spesies prokaryota berdasarkan urutan basa gen penyandi 16S rRNA dan gen penyandi protein. Biodiversitas. 3(7):292-296.

Sasaki E, Osawa R, Nishitani Y, Whiley RA. 2004. ARDRA and RAPD analysis of human and animal isolates of Streptococcus gallolyticus. J Vet Med Sci. 66:1467-1470. DOI: http://dx.doi.org/10.1292/jvms.66. 1467.

Schlegel L, Grimont F, Grimont PAD, Bouvet A. 2003. Identification of major Streptococcal species by rrn-amplified ribosomal DNA restriction analysis. J Clin Microbiol. 41:657-666. DOI: http://dx.doi. org/10.1128/JCM.41.2.657-666.2003.

Sudir, Suprihanto, Triny S. Kadir. 2009. Identifikasi Patotipe Xanthomonas oryzae pv. oryzae, Penyebab Penyakit Hawar Daun Bakteri di Sentra Produksi Padi di Jawa. Penelitian Pertanian Tanaman Pangan. 28(3):131-138.

Susilowati DN, Nurul H, Tasliah, Mulya K. 2010. Keragaman bakteri endofitik diisolasi dari empat varietas padi dengan metode ARDRA. Berita Biologi 10(2): 241-248.

Tasliah, Mahrup, Prasetiyono J. 2013. Identifikasi molekuler hawar daun bakteri (X. oryzae pv oryzae) dan uji patogenisitasnya pada galaur-galur padi isogenik. J Agrobiogen. 9(2):49-57.

Woese CR, Guttel R, Gupta R, Woller H. 1983. Detailed analysis of the higher order structure of the16S-like ribosomal ribonucleic acids. Microbiol Rev. 47:621669. 